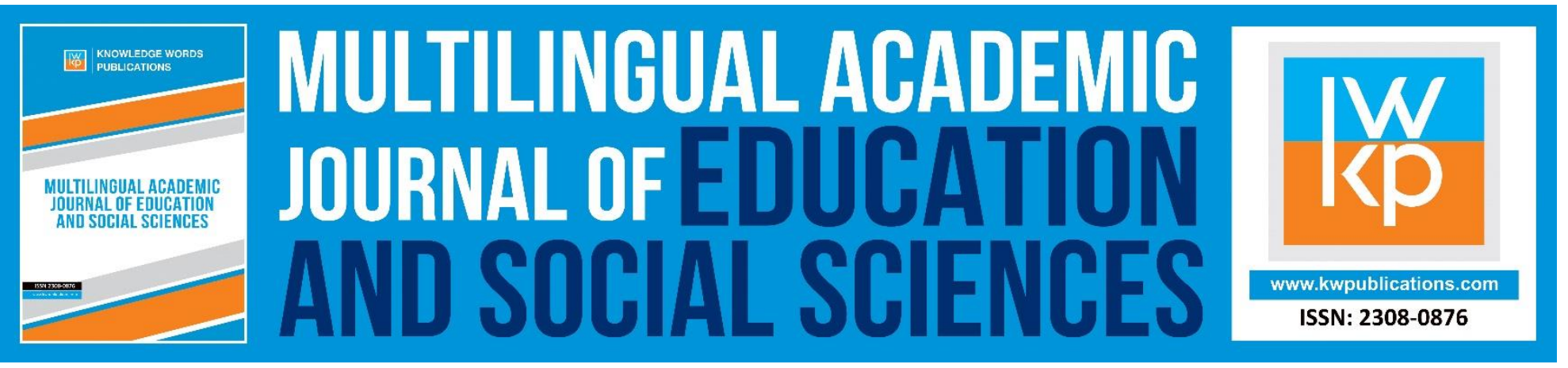

\title{
Local Tensions under the "Refugee Crisis": The Rise of Xenophobia in Chios after the EU-Turkey Statement of 2016
}

\section{Nikos Souzas, Georgios Diakoumakos, loulia Mermigka \& Yannis Pechtelidis}

To Link this Article: http://dx.doi.org/10.46886/MAJESS/v8-i1/6963

DOI: 10.46886/MAJESS/v8-i1/6963

Received: 02 June 2020, Revised: 09 July 2020, Accepted: 08 August 2020

Published Online: 23 September 2020

In-Text Citation: (Souzas, Diakoumakos, Mermigka \& Pechtelidis, 2020)

To Cite this Article: Souzas, N., Diakoumakos, G., Mermigka I., \& Pechtelidis Y. (2020). Local Tensions under the "Refugee Crisis": The Rise of Xenophobia in Chios after the EU-Turkey Statement of 2016. Multilingual Academic Journal of Education and Social Sciences, 8(1), 28-37.

\section{Copyright: (C) The Authors 2020}

Published by Knowledge Words Publications (www.kwpublications.com)

This article is published under the Creative Commons Attribution (CC BY 4.0) license. Anyone may reproduce, distribute, translate and create derivative works of this article (for both commercial and non-commercial purposes), subject to full attribution to the original publication and authors. The full terms of this license may be seen

at: http://creativecommons.org/licences/by/4.0/legalcode

Vol. 8, No. 1, 2020, Pg. 28 - 37

https://kwpublications.com/journals/journaldetail/MAJESS

JOURNAL HOMEPAGE

Full Terms \& Conditions of access and use can be found at https://kwpublications.com/pages/detail/publication-ethics 


\title{
Local Tensions under the "Refugee Crisis": The Rise of Xenophobia in Chios after the EU-Turkey Statement of 2016
}

\author{
Nikos Souzas, Georgios Diakoumakos, loulia Mermigka \& Yannis \\ Pechtelidis \\ University of Thessaly, Greece
}

\begin{abstract}
The north-eastern Aegean island of Chios became renown as a transit zone and a welcoming place for thousands of asylum seekers, who were passing through the island on their way to Northern Europe, in the summer of 2015. However, their movement was put into a halt after the EU-Turkey Statement of March 2016, which led to thousands of asylum seekers getting trapped in the Greek islands. A number of contentious events followed in Chios, including a port occupation by asylum seekers, a massive demonstration organized by locals, and violent xenophobic attacks against the asylum seekers. Therefore, this paper examines the hypothesis that the EU-Turkey Statement led to the rise of xenophobia in Chios. It also documents and analyses some of the key events that followed, taking into consideration the concepts of border regime and border externalization, based on a mixed qualitative approach including data from the local press, in-depth semi-structured interviews, and participatory observation.

Keywords: Border Externalization, Chios, EU-Turkey Statement, "Refugee Crisis", Xenophobia
\end{abstract}

\section{Early Solidarity and the Emergence of a Local Border Regime}

Social The island of Chios, located in the eastern Aegean, became famous as a transit zone and a welcoming place for thousands of asylum seekers in the summer and autumn of 2015 (Papataxiarchis, 2016) during the so-called "refugee crisis". It should be noted that "most of the Greek inhabitants of Chios come from families with a refugee past [...] Many persons who left Asia Minor, following the Greco-Turkish war of 1919-22, settled in Chios" (ECOI, 2016).A local woman with religious/philanthropic background, who helped voluntarily in the arrivals, told us: "Listening to the word refugee, you recall what you've heard since you were a child... what these people have gone through, who arrived from Asia Minor uprooted [...] From Alaçatı was my grandma, from Çeşme my grandpa".

Furthermore, certain solidarity groups helped in the self-organised camp in the central garden of the city, where the refugees had also stayed in 1922.A member of the "Social Kitchen" 
MULTILINGUAL ACADEMIC JOURNAL OF EDUCATION AND SOCIAL SCIENCES

Vol. 8 No. 1, 2020, E-ISSN: 2308-0876 @ 2020 KWP

told us that "[local] people [of Chios] helped very much... I was posting on Facebook: We need lentils, we need oil, we need tomatoes. And they came here, and they provided."

According to an official report, "as a response to the massive refugee flows to Europe during 2015, when a total 876,232 people arrived in Greece, [...] the 'hotspot approach' was adopted. [...] The objective of the hotspot approach was to assist frontline Member States, namely Italy and Greece [...]. In this respect, hotspots have been considered as solidarity tools" (Asylum Information Database, 2017).

However, hotspots could be viewed basically as a kind of bio-political management tool, since they "combine an EU integrated inter-agency approach, with the presence of agencies including Frontex and EASO" (Asylum Information Database, 2016). Actually, the progressive involvement of multiple players illustrates the emergence of a local border regime. According to this concept, "the border can only be conceptualized as being shaped and produced by a multiplicity of actors, movements and discourses... at the border there is no single, unitarian organizing logic at work. Instead, the border constitutes a site of constant encounter, tension, conflict and contestation." (De Genova et al. 2015:69)

In addition, the local border regime of Chios was further transformed due to the EU-Turkey statement, according to which "all new irregular migrants crossing from Turkey into Greek islands as from 20 March 2016 will be returned to Turkey" (European Council 2016). This statement is an effort to curb the migration flows through what has been coined as "border externalisation" (Mezzadra and Neilson, 2013) - a concept which refers to "the process of territorial and administrative expansion of a given state's migration and border policy to third countries" (De Genova et al. 2015:73).

Practically, the statement meant that asylum seekers, who until then merely passed through the island, could avoid the immediate threat of deportation only by applying for asylum in Greece. This turned Chios from a transit island to a place where asylum seekers were stranded -through a governmental decision on their geographical restriction in the island's premises- until their asylum application was examined, a process which could take more than a year. According to many critical reports, "containing asylum seekers on the Greek islands in substandard and appalling conditions [...] in the hope that it will deter others from coming is bad policy" (Human Rights Watch 2018)and "as conditions at the camps worsen, tensions are buildingbetween different groups of migrants and between the migrants and local communities" (IRIN, 2015 Khalid, Islam \& Ahmed (2019); Alzgool (2019); Umrani, Ahmed \& Memon (2015); Zin \& Ibrahim (2020).

We hypothesize that the changing border regime and the effects of externalisation took their toll on Chios and considerably transformed its features. In particular, we will examine the rise of several kinds of xenophobia on the island after the EU-Turkey statement, focusing on three key moments. Our study is based on a mixed qualitative approach, drawn from 14 in-depth semistructured interviews with asylum seekers, locals and humanitaria $\mathrm{n}$ workers, news reports from the four largest local media (Politis, Alitheia, Astraparis, Chios Press), and the participatory observation of a research team member.

\section{First Key Moment: Port Occupation against the Statement}

Following the EU-Turkey statement, starting on the March $20^{\text {th }}$, all new arriving asylum seekers were confined in the newly constructed Vial hotspot. It is often argued that the statement 
promotes the discrimination and tensions among asylum seekers: "In the first months following the EU-Turkey Statement, procedures exclusively prioritised Syrians, while other nationalities, including both adults and UAMs, were put on hold despite having stated their intention to seek asylum" (European Council on Refugees and Exiles, 2016). In fact, "[...] this differentiation creates frustration and inter-ethnic tensions" (ibid).

After twelve days of such conflicts and protests, the asylum seekers breached the hotspot gates. The following day, many of them, mostly Syrian families, marched and occupied the main island port, demanding that they should be allowed to continue their journey. Locals began to complain, arguing that the weekly occupation disrupted the port's operation and the island's commerce and daily life. The situation escalated on the night of April $7^{\text {th }}$. The asylum seekers found themselves surrounded by the police and by right-wing thugs and members of the neoNazi Golden Dawn Party. What followed was a violent evacuation of the port. An eye-witness humanitarian worker told us the following:

"[The refugees] put the women and children in the middle, men stood on the perimeter... [and] in order to break them, the fascists threw -in the middle- some fireworks like bombs [...] and there's incredible fear and shouting [...] A [refugee] guy would rise -they were all seated- [...] and he'd say, "calm down, calm down". As soon as this happened [...] a policeman would get in the [refugee] crowd [...] would take him and get out. The fascists were there. [The policeman] went through them. There insults began, there whacking began [by the fascists...] much whacking [...] This way they took many people [...] This went on for two hours [...] [In the end] the refugees surrendered, they brought them buses, they got them to the Souda [open camp] [...] It was worse than a third world scene."

Many of our interlocutors consider this violent evacuation a mayor's plan: "He said only 'if you don't evacuate it, I will leave you deal with the fascists'. [...] Nobody got arrested from the fascists, so somehow [...] they gave them a green light". In contrast, most of the local media reported a relatively peaceful evacuation, taking place after negotiations, and it was only a few days later that the extent of violence became known. 
MULTILINGUAL ACADEMIC JOURNAL OF EDUCATION AND SOCIAL SCIENCES

Vol. 8 No. 1, 2020, E-ISSN: 2308-0876 @ 2020 KWP

Table 1. Number of articles on asylum seeker crimes and anti-refugee rhetoric in the local media

\begin{tabular}{lcc}
\hline & $\begin{array}{c}\text { Reports on asylum seeker } \\
\text { crimes }\end{array}$ & $\begin{array}{c}\text { Reports on anti-refugee rhetoric and } \\
\text { activities }\end{array}$ \\
\hline June 2015 & 6 & 3 \\
July 2015 & 2 & 1 \\
August 2015 & 3 & 1 \\
September 2015 & 3 & 3 \\
October 2015 & 3 & 1 \\
November 2015 & 1 & 1 \\
December 2015 & 0 & 1 \\
January 2016 & 0 & 0 \\
February 2016 & 1 & 1 \\
March 2016 & 5 & 0 \\
April 2016 & 13 & 37 \\
May 2016 & 6 & 7 \\
June 2016 & 44 & 29 \\
July 2016 & 46 & 1 \\
August 2016 & 36 & 14 \\
September 2016 & 38 & 61 \\
October 2016 & 30 & 27 \\
November 2016 & 20 & 30 \\
December 2016 & 38 & 21 \\
\hline SOurce: Our content & 2016 & Althe \\
\hline
\end{tabular}

Source: Our content analysis on website of the newpapers Politis, Alitheia, Astraparis and ChiosPress.

The port occupation could well be the turning point, as illustrated by the discourse of the local media, which soon began to report asylum seeker crimes and anti-refugee rhetoric. According to Table 1, until the EU-Turkey statement of March 2016 there were typically less than 5 articles per month on asylum seeker crimes by the four media examined. Afterwards, these numbers rose to often 30 or more articles per month. However, according to the police data, crime rates didn't increase that much in 2016: in particular, 8.2 thefts per 10,000 inhabitants were recorded in 2015 in the islands affected by the "refugee crisis", compared to 13.8 in 2016 
MULTILINGUAL ACADEMIC JOURNAL OF EDUCATION AND SOCIAL SCIENCES

Vol. 8 No. 1, 2020, E-ISSN: 2308-0876 @ 2020 KWP

and, in any case, these crime rates pale compared to those recorded in the Greek capital of Athens which reached almost 70 thefts per 10,000 in the same period (Hellenic Police, 2017). ${ }^{1}$

\section{Second Key Moment: Panchiaki Struggle Committee's Demonstration}

The second key moment took place in September 2016, when the newly formed Panchiaki Struggle Committee addressed the city council and called for a demonstration on the $28^{\text {th }}$. According to the call, this was an action against the transformation of a peaceful and wealthy island into a kind of "prison" for hundreds of asylum seekers, a policy decided without consulting with the locals, and degraded the islands' standard of living through delinquency and fear, repelled tourism, and put national sovereignty at risk. A striking 2,000 to 3,000 otherwise mild locals attended the demonstration and asked for return to social and financial normality and tighter border control, including many members of the city council. This is quite impressive compared to the island population of 53,000.

Panchiaki's statements are very carefully articulated and intentionally non-extremist. Quoting Panchiaki's call, "we cannot accept any other facility in our island, no matter how they call it... because very simply our island cannot carry the double burden of the entrance, on the one hand, but also of the permanent stay on the other, of thousands of people... We are against policies, not people" (Politis, 2016a). However, it should be noted that the presence of asylum seekers is referred to as a "burden" -that is, a source of worry that is difficult to bear- revealing an implied xenophobia. Moreover, the denial of racism is, as illustrated by van Dijk, a well-known feature of racist discourse in order to avoid negative impression as, generally, racism is considered to break social norms (Dijk, 1992).

While xenophobic discourse is often denied or downplayed in public, it becomes more evident if we study some of the less formal statements of Panchiaki's members. For instance, in a quite exaggerated speech delivered during this demonstration, the speaker said that "our villages have been transformed to a ghetto of criminals [...] residents are threatened with knives when they think to protect their property [...] drunk migrants terrorise drivers and throw stones at passing-by vehicles" (Politis, 2016b).

Another aspect of xenophobia lies in a latent Islamophobic discourse, where asylum seekers are constructed as unwelcome or threatening due to their religion. According to an official report, "in some islands, in particular, numbers of persons hosted are disproportionate as to the islands' population" (Papageorgiou, 2017). Given that, a percepted "danger" of Chios' islamisation and of potential demands of the neighbouring Muslim Turkey emerged. For instance, a member of Panchiaki told us that when "you create a minority in the islands, you give the right to Turkey to ask tomorrow for land exchanges according to religion. And with the birth deficit of the Greeks, and the high birth rate of the Muslims [...] Lesvos today has 25\% to 30\% Muslim population, tomorrow they will get the majority, they will reach $55 \%$. And this tomorrow is in 5 years $[\ldots] " .$.

It should be noted that islamophobia amongst the locals is also connected to a concern about the supposed bad impact on Chios' tourism, silencing that it was never quite developed

\footnotetext{
1. Conversion to thefts per 10,000 people was done according to the population data of the Hellenic Statistical Authority, available at https://www.statistics.gr/el/statistics/-/publication/SPO18/-
} 
MULTILINGUAL ACADEMIC JOURNAL OF EDUCATION AND SOCIAL SCIENCES

Vol. 8 No. 1, 2020, E-ISSN: 2308-0876 @ 2020 KWP

anyway. For instance, the president of the hotel owners began a statement with the standard denial of racism: "This stance isn't motivated by racism or hatred towards foreigners. [...] But we have to reclaim our top-selling product: tourism [...] Which traveller and which visitor will book a holiday at a hotel, or other accommodation, knowing that a family of Muslim refugees is being housed right next door? [...] When you're on holiday and you've planned a trip for months, the last thing you want to... [is] waking up to the sound of Muslim prayers" (Deutsche, 2017).

Using the terms of Laclau and Mouffe (1985), the xenophobic discourse is based on a chain of equivalence, where all asylum seekers are considered to be dangerous because they are criminals, Muslims, or even carriers of diseases, ignoring the vast differences amongst them - for instance, that a number of them are Christians or not religious.

\section{Third key moment: Souda Attacks}

A third key moment took place on the $16^{\text {th }}$ and $17^{\text {th }}$ of November 2016 , a few days after two PMs of the neo-nazi Golden Dawn visited the island. Several dozens of right-wing thugs attacked from above on the overcrowded Souda camp, which was located inside a moat in the centre of the city of Chios. Asylum-seekers told us: "They attacked us from both sides -from the castle side and from the houses side- and they threw molotov and stones. And one of my friends had really serious injury in his head" and "so, you are down and a lot of [molotov] cocktails coming to you. That's how it happened, and the police doing nothing." Another asylum-seeker said that "when the attack happened, we were afraid for our lives and we ran out of the camp [...] People were screaming, children were crying" (Amnesty International, 2017).

While this was not the first, nor the last attack against the Souda camp, it was by far the most violent. However, even though most of our interlocutors, as well as Amnesty International reports, attributed the attack to right-wing thugs, some media claimed that it was the asylumseekers which attacked the "terrified" locals who only defended. Representing UNHCR's controversial non-political policy, its representative Philippe Leclerc equated victims and offenders, stating that "I strongly condemn any acts of violence, resulting both in the local population and the refugees being seriously hurt" (Independent, 2016).

Most of the locals kept themselves silent and uninvolved in relevance with the two days pogrom. As a well-known local writer, active in solidarity actions, claims, though bourgeois and cosmopolitans, people of Chios carry a collective fear after the 1822 Chios Massacre by the Ottomans that makes them afraid authority, develop an individualistic behaviour according to their interests and mind their own businesses (Makridakis, 2015).

\section{Conclusion}

Since the vast majority of xenophobic practices and discourses arose only after the EU-Turkey Statement, it seems that the main hypothesis is confirmed and the process of border externalisation led to the rise of xenophobia in the island. However, we should be careful not to give the impression of a complete transformation of Chios from a place of solidarity to a place or xenophobia within days. Certain aspects of our data indicate that some incidents of financial exploitation -such as requesting 5 euros in order to allow asylum seekers to charge their mobilesand racism existed even before the Statement. A local activist told us about a specific xenophobic example: "People stayed in some half-destroyed UNHCR tents set up on a plateau at Mersinidi outside the cemetery. It was a grotesque scene [...] their clothes were wet and they were drying 
MULTILINGUAL ACADEMIC JOURNAL OF EDUCATION AND SOCIAL SCIENCES

Vol. 8 No. 1, 2020, E-ISSN: 2308-0876 @ 2020 KWP

them on the graves [...] And the villages [...] believed that the refugees, since they are also Muslims, were desecrating the graves of their relatives [...] There were also instances when the people went to swim in a small beach below Mersinidi and many [locals] left the beach because they didn't want to swim with the refugees, because they were afraid they had infectious diseases."

In conclusion, it would be more accurate to say that the EU-Turkey Statement led to a dominant solidarity discourse being replaced by a xenophobic discourse. Refraining ourselves from any essentialising and deterministic approach about the rise of xenophobia in Chios, we should take into account different scales and conjunctures of racism and xenophobia (Kasparek et al. 2017), from the transnational to the national to the local. That is, from the structural xenophobia of the transnational policies of border externalisation, from the enfeeblement of the sovereignty of the nation state and the rise of nationalism, to the excision of the border island from the mainland Greece in the national decision of geographical restriction, to the media's xenophobic discourses, we are also able to weigh other cultural factors which have to do with social memory, local and religious identity and accumulation of resentment.

\section{Acknowledgements}

This research is co-financed by Greece and the European Union (European Social Fund-ESF) through the Operational Program "Human Resources Development, Education and Lifelong Learning 2014-2020" in the context of the project "Border Regimes: Political and Cultural Dimensions of the Refugee Crisis in the Case of Chios 2015-16" (MIS 5005539). An early version of this paper was presented at the Migration Conference 2019 (18-20 June 2019, Bari).

\section{References}

Alzgool, M. (2019). Nexus between green HRM and green management towards fostering green values. Management Science Letters, 9(12), 2073-2082.

Amnesty International. (2017). EU: Human rights cost of refugee deal with Turkey too high to be replicated elsewhere. Available at www.amnesty.org/en/latest/news/2017/02/euhuman-rights-cost-of-refugee-deal-with-turkey-too-high-to-be-replicated-elsewhere/

Asylum Information Database. (2016). Wrong counts and closing doors: The reception of refugees and asylum seekers in Europe. Available at http://www.asylumineurope.org/sites/default/files/ shadowreports/aida_wrong_counts_and_closing_doors.pdf

Asylum Information Database. (2017). Country Report: Greece, 2016 Update. Available at https://www.asylumineurope.org/sites/default/files/reportdownload/aida_gr_2016update.pdf

De Genova, N., Mezzadra, S., \& Pickles, J. (ed.) (2015), New keywords: Migration and borders. Cultural Studies, 29(1), 55-87.

Welle, D. (2017). Greece's hotel owners want tourists not refugees. Available at https://www.dw.com/en/greeces-hotel-owners-want-tourists-not-refugees/a-39176253

ECOI. (2016). Report of the fact finding mission by Ambassador Tomáš Boček Special Representative of the Secretary General on migration and refugees to Greece and "the former Yugoslav Republic of Macedonia". Available at https://www.ecoi.net/en/file/local/1060038/1226_1463648981_result-details.pdf 
MULTILINGUAL ACADEMIC JOURNAL OF EDUCATION AND SOCIAL SCIENCES

Vol. 8 No. 1, 2020, E-ISSN: 2308-0876 @ 2020 KWP

European Council. (2016). EU-Turkey Statement. Press release available at https://www.consilium.europa.eu/en/press/press-releases/2016/03/18/eu-turkeystatement/

European Council on Refugees and Exiles. (2016). The implementation of the hotspots in Italy and Greece - A study. Available at http://www.refworld.org/docid/584ad1734.html

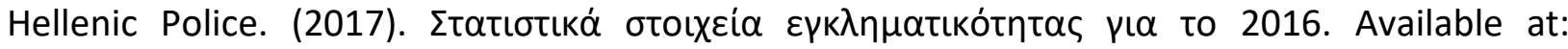
http://www.astynomia.gr/index.php?option=ozo_content\&lang=\&perform=view\&id=64 341\&Itemid $=1149$

Human Rights Watch. (2018). Why Greece Should \#OpenThelslands. Available at https://www.hrw.org/news/2018/03/19/why-greece-should-opentheislands

Independent. (2016). Far-right mob attacks refugee camp with Molotov cocktails and rocks on Greek island of Chios. Available at www.independent.co.uk/news/world/europe/refugee-risis-latest-greek-islands-chioscamp-attack-far-right-firebombed-molotov-cocktails-rocks-a7425386.html

IRIN. (2015). Greek financial showdown overshadows refugee crisis. Available at http://www.thenewhumanitarian.org/analysis/2015/06/30l

Kasparek, B., Kirchhoff, M., Neuhauser, J., \& Schwiertz, H. (2017). The return of the national? Migration, borders and nationalism. Movements, 3(2), 147-161.

Khalid, N., Islam, D. M. Z., \& Ahmed, M. R. M. (2019). Sentrepreneurial Training and Organizational Performance: Implications for Future. Humanities \& Social Sciences Reviews, 7(2), 590-593.

Laclau, E., \& Mouffe, C. (1985). Hegemony and Socialist Strategy: Towards a Radical Democratic Politics. London: Verso.

Makridakis, G. (2015). To $\mu \pi \lambda \varepsilon$ vnoi. Available at http://yiannismakridakis.gr/?p=5751

Mezzadra S., \& Neilson, B. (2013). Border as method, or, the multiplication of labor. Durham: Duke University Press.

Papageorgiou, I. (2017). International protection in Greece: Background information for the LIBE Committee delegation to Greece 22-25 May 2017. Report of the Policy Department for Citizen's Rights and Constitutional Affairs for European Parliament's Committee on Civil Liberties, Justice and Home Affairs, available at

https://www.ecoi.net/en/file/local/1401618/ 1226_1497249698_ipol-stu-2017-583145en.pdf

Papataxiarchis, E. (2016). A big reversal: The 'european refugee crisis' and the new patriotism of 'solidarity'. Synchrona Themata, 132-133, 7-28.

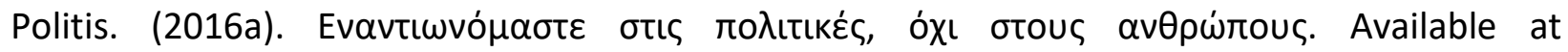
www.politischios.gr/koinonia/enantionomaste-stis-politikes-ohi-stoys-anthropoys

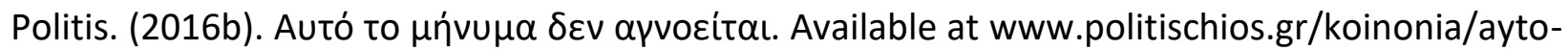
minyma-den-agnoeitai-binteo-foto

Dijk, V. T. (1992). Discourse and the Denial of Racism. Discourse \& Society, 3, 87-118.

Umrani, W., Ahmed, U., \& Memon, P. (2015). Examining the absorptive capacity construct: A validation study in the Pakistani banking context. Management Science Letters, 5(12), 1053-1058. 


\section{MULTILINGUAL ACADEMIC JOURNAL OF EDUCATION AND SOCIAL SCIENCES}

Vol. 8 No. 1, 2020, E-ISSN: 2308-0876 @ 2020 KWP

Zin, M. L. M., \& Ibrahim, H. (2020). The Influence of Entrepreneurial Supports on Business Performance among Rural Entrepreneurs. Annals of Contemporary Developments in Management \& HR (ACDMHR), 2(1), 31-41. 